\title{
Traducerea infidelă și scopurile traductive: Descoperirea Americii de Joachim Heinrich Campe, în versiune românească ${ }^{\dagger}$
}

\author{
Iulia Elena Zup ${ }^{\mathbb{A} \mathbb{R}^{\circledR \star}}$ \\ Facultatea de Drept, Universitatea „Alexandru Ioan Cuza”, Bd. Carol I 11, 700506 Iași, România
}

\begin{tabular}{|c|c|}
\hline Despre articol & Rezumat \\
\hline $\begin{array}{l}\text { Istoric: } \\
\text { Primit } 6 \text { august } 2021 \\
\text { Acceptat } 14 \text { august } 2021 \\
\text { Publicat } 18 \text { august } 2021 \\
\text { Cuvinte-cheie: } \\
\text { traducere } \\
\text { literatură veche } \\
\text { analiză comparată } \\
\text { glose }\end{array}$ & $\begin{array}{l}\text { Prezenta lucrare investighează scopul utilizării anumitor strategii traductive în } \\
\text { varianta în limba română a romanului Die Entdekkung von Amerika (1781) de } \\
\text { Joachim Heinrich Campe, tradusă din germană de negustorul și dascălul braşo- } \\
\text { vean Nicola Nicolau și publicată la Tipografia Universității din Buda în } 1816 \\
\text { sub titlul Descoperirea Americii. Pornind de la teoria scopului traducerii enun- } \\
\text { țată de Hans Vermeer, sînt analizate scopurile producerii variantei în limba ro- } \\
\text { mână, prin comparație cu cele ale redactării textului original și ale traducerilor în } \\
\text { alte limbi. La nivel textual, prin analiză comparativă, sînt evidențiate strategiile, } \\
\text { în special omisiunile și interpolările, care ajută la realizarea scopurilor traducă- } \\
\text { torului sau ale textului. Astfel, prin transferul dintre cultura sursă și cea țintă, } \\
\text { sînt constatate menținerea țelurilor iluministe pedagogice, de instruire a maselor } \\
\text { privitor la virtuțile morale și cunoștințele istorice și geografice, și adăugarea celui } \\
\text { de cultivare a limbii române. }\end{array}$ \\
\hline
\end{tabular}

\section{Introducere. Scopul traducerii și al traducătorului}

În 1978, lingvistul german Hans Josef Vermeer enunța în revista „Lebende Sprachen” teoria scopului ('Skopostheorie'), conform căreia strategiile traductologice sînt determinate de un anumit scop, o anumită intenţionalitate a acțiunii traductive. Astfel, traducerea are un scop comunicativ în contextul în care este receptat de publicul țintă, textul sursă fiind un prilej pentru furnizarea de informații în cultura receptoare. În funcție de cititor și contextul receptării, sînt menținute, alterate sau introduse scopuri ale textului prin producerea traducerii. Acțiunea traductivă este una intențională, traducerea reprezentînd producție de text într-un anumit context țintă, în anumite scopuri și pentru cititori care îl vor lectura în anumite circumstanțe (Vermeer, 1978). Așadar, teoria scopului se detașează de și depășește o analiză lingvistică statică în care accentul este pus pe identificarea echivalențelor, a erorilor, a fidelității traducerii, acestea fiind analizate acum ca mijloace de realizare a scopurilor - ale textului sursă, ale textului țintă, ale lecturii. Prin acțiunea lor, traducătorii-mediatori culturali-pot beneficia de libertate în menținerea scopurilor textului sau în adăugarea altora, însă această libertate aduce cu sine și un grad de responsabilitate (Agori, 2005). Din această perspectivă, ei ocupă o poziție centrală în cadrul fenomenului de transfer cultural.

Rolul de pivot al traducătorului a fost evidențiat și de Delisle \& Woodsworth (1995), acesta fiind înfățişat ca unul din factorii evoluției culturale, care contribuie decisiv la dezvoltarea limbilor și literaturilor naționale, și de Even-Zohar (1990, p. 53), care identifică traducătorul ca unul din factorii esenţiali ai interferenței culturale. Teoriei scopului traducerii li se alătură noi teorii care se axează pe procesele dinamice în ambele sensuri ale transferului cultural, pe intersecțiile societăţilor şi culturilor, şi anume 'histoire croisée' (Werner \& Zimmermann, 2006), fenomen cultural din care acțiunea traductivă este parte.

\footnotetext{
${ }^{\dagger}$ Aceastã lucrare este realizatã cu sprijinul unui grant oferit de Ministerul Cercetãrii, Inovãrii și Digializãrii, CNCS/ CCCDI - UEFISCDI, numãr proiect PN-III-P1-1.1-TE-2019-0721 din cadrul PNCDI III.

*Adresă de corespondență: iuliazup@gmail.com.
} 
Iulia Elena Zup

Epoca în care traducerea și traducătorul au jucat fără îndoială un rol esențial pentru transferul cultural şi dezvoltarea limbii și literaturii românești este epoca iluministă (a doua jumătate a secolului al XVIIIlea şi începutul secolului al XIX-lea), în care se intensifică traducerea de texte laice din limbi moderne (germană, italiană, franceză), spre deosebire de perioada anterioară, cînd predominau traducerile de texte bisericești din greacă și slavonă, sau din latină (în provinciile românești ce făceau parte din Imperiul Habsburgic) (Gheție, 1982, p. 77-78). Interesul pentru textele laice reprezintă pe de o parte o desprindere a culturii și științei de instanțele bisericești, iar pe de altă parte o primă etapă de modernizare a limbii române (Gheție, 1982, p. 65), prin fluxul de vocabular (specializat), introdus prin intermediul traducerii.

În acest context este tradus în română romanul Die Endekkung von Amerika al pedagogului german Joachim Heinrich Campe, de negustorul brașovean Nicola Nicolau. Textul, analizat în acest articol, prezintă interes întrucît, prin analiza scopurilor urmărite de autor și de traducători, inclusiv cel român, se poate observa circulația ideilor iluministe în spațiul european. Scopurile sînt realizate la nivel textual atît declarativ, prin cuvînt înainte sau postfaţă, narativ prin intermediul discursului, cît și la nivel traductiv, prin mijloacele de care dispune traducătorul. Astfel, lucrarea de faţă îşi propune a trata dintr-o perspectivă nouă un text care a mai intrat în vizorul unor valoroase cercetări recente, ale echipei conduse de Gînsac (2017) în cadrul proiectului Practici de traducere a numelor proprii în scrisul românesc premodern: 17801830, care se apleacă asupra traducerilor numelor proprii în această lucrare, și ale lui Tatay (2011), care tratează gravurile în metal, din volumul în română.

\section{Die Entdekkung von Amerika}

În 1781, este publicată la Hamburg Die Entdekkung von Amerika. Ein angenehmes und nüzliches Lesebuch für Kinder und junge Leute, o serie de trei volume care urmărește descoperirea Lumii Noi: primul volum despre Columb, al doilea despre Cortes și al treilea despre Pizarro. În română sînt traduse primele 18 povestiri din totalul de 20 din primul volum, Kolumbus oder die Entdekkung von Westindien. Autorul german, Joachim Heinrich Campe (1746-1818), a fost teolog, lingvist, pedagog iluminist, autor de cărți pentru copii şi tutore al fraților Humboldt. A fost unul dintre cei mai de seamă reprezentanți ai curentului educațional denumit filantropism (Blamires, 2009, p. 23), alături de Johann Bernhard Basedow, Christian GottfhilfSalzmann și Eberhard von Rochow, curent ale cărui activități principale a fost redactarea de cărți pentru copii, în scop pedagogic. Prin intermediul acestor volume era vizată educația morală, ce putea fi realizată cel mai facil, în viziunea filantropismului, prin intermediul poveștilor. Operele didactice germane urmează modelul literaturii iluministe pentru tineret din Franța, structurată sub formă de conversații didactice în cadru familial: Emilé sau despre educație (1762) de Jean-Jaques Rousseau; Magasin des Enfants (1756) de Jeanne-Marie Le Prince de Beaumont; Conversations d'Emilie (1774) de Louise d'Epinay; Entretiens, drames et contes moraux, a l'usage des enfans (1778) de Marie-Elisabeth de la Fite. Metoda de educație propusă de literatura pedagogică iluministă era socratică, curiozitatea copilului, manifestată în roman sub formă de întrebare, era cea care ghida procesul de învăţare. Operele arată că comportamentul uman poate avea consecințe, bune sau rele (Dietz, 2019, p. 204). Dintre lucrările curentului filantropist, romanele lui Campe se bucură de cel mai răsunător succes, apărînd în nenumărate ediții și fiind traduse în multe limbi. La momentul în care publică Die Entdekkung von Amerika, Campe era deja celebru datorită romanului Robinson der Jüngere (1779), o adaptare pentru copii a operei lui Defoe, ce a fost tradusă și în română la 1817 și 1835. Popularitatea operelor lui Campe în spațiul românesc este grăitoare prin faptul că există patru traduceri ale operelor sale (Camară, 2017, p. 25): Descoperirea Americii; Theophran sau Iscusitul sfätuitor pentru neiscusita tinerime (Buda, 1833), tradusă de Ioan Theodorovici după Theophran oder der erfahrene Rathgeber für die unerfabrene Jugend (1783); Robinson Cruzoe seau Intămplärile cele minunate a unui tânăr, tradusă de Vasiel Drăghici (Iași, 1817 și 1835) după Robinson der Jüngere; Cărticica invățăturilor morale pentru copii de școală, tradusă de Gheorghe Lazăr după Sittenbüchel für Schulkinder.

Și Descoperirea Americii devine un bestseller al epocii, apărând în nenumărate ediții și republicări în 
germană $^{1}$. În cuvîntul înainte, semnat la 1781 și intitulat Von der Absicht dieses Buchs [Despre intenția acestei cărți], Campe afirmă că unul dintre scopurile publicării textului este de a suplini lipsa de cărți pentru copii și tineret, și consideră că continuarea firească a volumelor sale anterioare, Kleine Kinderbibliothek [Biblioteca pentru copii] și Robinson, este Descoperirea Americii, în sensul unei progresii a stilului și informațiilor transmise. Astfel, tînărul cititor primește o educație iluministă, pe de o parte prin transmiterea de date istorico-geografice, pe de altă parte, prin insuflarea virtuților morale - chiar prin arătarea adevăratei naturi umane, în complexitatea sa, prin oferirea de modele sau anti-modele pe parcursul romanului, prin indicarea conduitei corecte față de alte ființe umane. Spre deosebire de lucrările anterioare, scrise pentru copii mai mici, povestirea este întreruptă mai rar de dialog, întrucît adolescenții nu necesită atît de multe lămuriri. Interesul lui Campe pentru popularizarea științei istoriei este evident și din publicarea altor lucrări istorice sau de călătorie, din ale căror titluri reiese scopul său de iluminare a maselor și de răspîndire a cunoștințelor ${ }^{2}$. În relatarea evenimentelor din Descoperirea Americii, Campe se bazează pe scrieri istorice, iar atunci cînd întîlnește informații contradictorii, prezintă punctul de vedere a lui William Robertson. Istoricul scoțian Robertson publicase în 1777 The History of America în trei volume - o operă a iluminismului european, ce fusese tradusă în germană chiar în același an al apariției de Johann Friedrich Schiller și publicată la Leipzig (Geschichte von Amerika). Această lucrare se bucura de un mare succes în Europa, apărînd în mai multe ediții și fiind tradusă și în italiană, spaniolă, olandeză, franceză. Probabil tot de la Robertson, Campe preia ideea de evidențiere a calităților amerindienilor, contrazicînd astfel alți istorici, care afirmaseră caracterul degenerativ al acestora (Buffon, de Pauw), și pledează pentru toleranță (Petroff, 2017, p. 3). În ciuda dorinței de a relata adevărul istoric, Campe recunoaște că a fost nevoit să mai domolească anumite descrieri ale caracterului uman, avînd în vedere cititorul țintă. Tot în cuvîntul înainte, Campe arată că în anul apariției, volumul este deja tradus în Paris, de Junker, întrucît și în Franța se resimțea o lipsă a genului de romane pentru tineret.

\section{Traducerile în alte limbi}

Volumul se bucură de atît de mult succes, încît, la scurt timp după apariția sa în Germania, este tradus în mai multe limbi europene și publicat chiar în mai multe ediții. De remarcat este că traducătorii sînt, la rîndul lor, iluminiști și propagatori ai ideilor iluministe în țara lor. Traducătorul în limba franceză, Georges Adam Junker, menționat de Campe și în cuvîntul înainte, tradusese și Robinson der Jüngere și operele lui Lessing în franceză, precum și unele lucrări istorice ${ }^{3}$. Spiritul său iluminist ni se relevă însă mai cu seamă din cărțile sale de autor: de lingvistică germană, despre teatrul german, manuale de limba și literatura germană. Traducerea în franceză se bucură la rîndul ei de o receptare activă, fiind publicată în mai multe ediții (Hamburg, 1782, La Découverte de l'Amérique pour l'Instruction et l'Amusement des Enfans

\footnotetext{
${ }^{1}$ Pînă în 1816, anul tipăririi traducerii în română, apare în edițiile și republicările: 1781 - Tübingen: Frank und Schramm; Hamburg: Bohn; 1782 - Tübingen: Frank und Schramm; Tübingen: Frank und Balz; Hamburg: Bohn, ediție ce conține și o imagine, reprezentînd pe Columb pășind pentru prima oară pe Lumea Nouă, cu traducerea titlului acesteia în franceză; 1783 - Tübingen; Frank und Schramm; 1784 - Straßburg: P.J. Dannbach, cu traducerea în limba franceză a primei pagini, nota editorului în franceză și mențiunea că sînt păstrate aceleași personaje ca în Robinson: Johann, Gottlieb, Fritz, Hans, Lotte, Christel; Leipzig: Lauffer; 1785 - Tübingen: Frank und Schramm; 1790/1 - Braunschweig; 1794 - Braunschweig: In der Schul-buchhandlung; 1796 - Braunschweig: Schulbuchhandlung; 1798 - Tübingen: Balz und Schramm; 1800 Reuttlingen: J. J. Fleischhauer; 1801 - Braunschweig: in der Schulbuchhandl; 1804 - Altona: Bechtold; 1807 - Braunschweig: Schulbuchhandlung; 1808 - Reuttlingen Joh. Jak. Fleischhauer; 1810 - Viena: B. Bauer; 1813 - Viena: Bauer, care conține o gravură în metal semnată de von Friedrich Weber; 1814 - Reutlingen: Fleischhauer \& Bohm; 1815 - Reutlingen: in der J.J. Mäcken'schen Buchhandlung. Este publicată chiar și o ediție bilingvă în germană și engleză, simplificată, cu scopul facilitării învățării limbii engleze de copiii germani: 1808, Oldenburg Schulze: The discovery of America for the use of children and young persons; ein Lesebuch für Anfänger in der englischen Sprache, nebst einem Wortregister mit beygefügter Aussprache, auf die in England selbst übliche Weise bezeichnet.

${ }^{2}$ Philosophische Gespräche über die unmittelbare Bekanntmachung der Religion und über einige unzulängliche Beweisarten derselben (Berlin, 1773), Erste Sammlung merkwürdiger Reisebeschreibungen für die Jugend (Hamburg, 1785-1793; Braunschweig, 1794-1801), Geschichte der französischen Staatsumwälzung (Frankfurt/Leipzig, 1792).

${ }^{3}$ Pensées libres sur différentes parties de l'art de la guerre (Paris, 1800).
} 
et des jeunes Gens, cu noi ediții în 1784, 1798, 1803, 1817), traduceri și ediții noi și în anii 1785, 1797, $1810,1827,1836,1838,1845$.

Traducătoarea în limba engleză (Columbus or The discovery of America: as related by a father to his children, and designed for the instruction of youth, Sampson Low, Londra, 1799 ${ }^{4}$, cu noi ediții în 1811 și 1828) este Elizabeth Helme (1772-1813), director de școală în Brentford și autoare de succes. Printre operele sale se numără numeroase romane didactico-istorice pentru tineret, scrise tot sub formă dialogată, precum Maternal instruction or Family conversations on moral and entertaining subjects: interspersed with history, biography, and original stories: designed for the perusal of youth (1804), The history of Rome: from the foundation of the city to the fall of the eastern empire, related in familiar conversations, by a father to his children (1808) sau The history of England: related in familiar conversations, by a father to his children (1834). La sfârșitul sec. al XVIII-lea, în Regatul Unit traducerea de texte reprezenta într-adevăr o practică ce asigura venituri suplimentare, însă se poate observa din titlurile de mai sus că Helme adoptă stilul iluminist didactic, considerat în acele vremuri a fi potrivit scriiturii feminine.

Despre variantele în ebraică și idiș ne parvin mai multe informații datorită cercetărilor lui Shavit (1993, 1995), aceste traduceri fiind cu atît mai relevante pentru scopurile lucrării de față cu cît, ca și traducerea în română, textul este modificat și adaptat pentru a corespunde cerințelor culturii receptoare. Conform Shavit (1995), textul a fost ales spre a fi tradus în ebraică, întrucît putea fi transformat foarte facil astfel încît să fie prezentat ca un text istorico-geografic, căci textele ficționale, fie ele chiar traduceri, nu corespundeau în acea perioadă canonului evreiesc. Elementul narativ al ramei povestirii sub formă dialogată, caracteristic curentului filantropist, este înlăturat, iar evenimentele sînt povestite din perspectivă auctorială. Această modificare a textului sursă ar corespunde normelor de traducere ale sistemului iudaicevreiesc, a unei abordări culturale a textului original, practica traducerii fiind văzută în cultura evreiască ca o activitate creativă, care urmează legile sale proprii. Astfel, statutul practicii traducerii nu se deosebea cu mult de practica producerii de texte originale (Shavit, 1993, p. 757). Scopul traducerii este însă, și în acest caz, unul de iluminare a maselor și de lărgire a orizonturilor istorice: „Translating Campe was not perceived of in terms of writing fictional narratives, nor in terms of mere adventure stories about the discovery of America or any such wonderful journey, but in terms of creating a repertoire of historical awareness and creating tools for implementing a new and enlightened Weltanschauung" (Shavit, 1995, p. 78). Prima traducere în ebraică datează din 1807 (Altona), traducătorul Moshe Mendelssohn-Frankfurt transformînd opera lui Campe într-o relatare istorico-geografică. Numele lui Campe nu este menționat pe copertă sau prima pagină, în schimb traducătorul afirmă în prefață: „[volumul] a fost scris, adunat și compus în limba ebraică din cărți populare, într-o limbă clară și simplă, pentru a face cunoscută tineretului poporului Israel frumusețea acestei limbi și a-l învăța despre lucrările și minunile lui Dumnezeu, pe care le înfăptuiește pretutindeni." 5 Omiterea numelui de pe copertă sau prima pagină nu ar fi reprezentat o lipsă de respect sau o tentativă de plagiat, căci, în introducere, traducătorul Mendelssohn își exprimă prețuirea pentru Campe, pe care îl caracterizează cu adjectivele „inteligent, iluminat și sincer” (Shavit, 1993, p. 758). Așadar, traducătorul adaugă, față de scopurile enunțate de Campe în prefaţa din 1781, altele două. Primul ar fi arătarea frumuseții limbii ebraice, aflată în concurență cu idiș și alte limbi europene, ale țărilor în care trăiau comunitățile evreiești, și astfel cultivarea acestei limbi și a identității evreiești - un scop enunțat, de altfel, și în postfața traducerii românești privitor la limba română. Al doilea țel este învățarea tineretului despre măreția lui Dumnezeu, care reprezintă o modificare a scopului enunțat de Campe, și anume învăţătura morală, dar nu neapărat religioasă. Acest scop religios este menit tot a cultiva identitatea evreiască. Din 1810 datează traducerea lui Hirsch Baer Hurwitz, cunoscut și sub numele de Hermann Bernard, evreu care trăia în Rusia. Conform Shavit, textul este tradus din nou în ebraică, la numai trei ani de la traducerea lui Mendelssohn, căci aceasta nu era cunoscută în Rusia sau era greu de procurat.

${ }^{4}$ Traduceri în engleză ale Descoperirii Americii apar în același an la Londra, la o altă editură - J. Johnson, și în Dublin în anul 1800.

5în traducerea mea, după traducerea în germană a lui Shavit (1993, p. 757). 


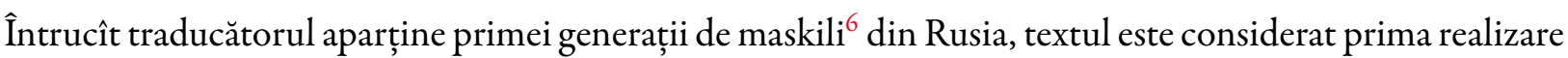
importantă pentru maskilul evreiesc rusesc - sau Haskalah, iluminarea evreiască, mișcare intelectuală de la sfîrșitul sec. al XVIII-lea, care pleda pentru adoptarea ideilor iluministe. Textul lui Campe a fost foarte popular printre scriitorii Haskalah, evreii maskili începîndu-şi cariera de scriitori prin traducerea acestei cărți, în ciuda faptului că existau deja multe ediții (Shavit, 1995, p. 77). Astfel, alte variații care pun accent pe conținutul istoric sînt traducerea lui Mendel Lefin (Liov, 1818) și a lui Mohr (Liov, 1846) (Shavit, 1993, p. 759).

Traducerea în ebraică a fost atît de populară, încît comunitatea evreiască, răsfirată pe tot întregul Europei, cunoștea datele istorice despre descoperirea Americii, ceea ce ar fi contribuit, într-o fază ulterioară, la o fascinație pentru Lumea Nouă și chiar la emigrarea acolo (Völpel \& Shavit, 2002). La 1817, textul este tradus și în idiș de Chaikel Hurwitz, unul dintre iniţiatorii iluminismului ebraic. De abia în 1823 (Vilna) este tradusă în idiș versiunea integrală.

Traducerea în greacă (1820), realizată de Ioannis Billiaros și revizuită de Giorgios Russiadis - lingvist ce publică mai multe lucrări de lingvistică greacă în limba germană, a fost utilizată în școli și este, de asemenea, o traducere infidelă, întrucît, în locul tatălui, naratorul este un pedagog responsabil cu educația mai multor copii (Polioudakis, 2008, p. 170-171). Numele germane sînt înlocuite cu nume grecești. Volumul este tradus și în daneză (1813), polonă (1809), olandeză (1782-1783), portugheză (1836), suedeză (1813-1814), spaniolă (1803), slovacă (1840), maghiară (1783).

\section{Traducerea în română}

Pe teritoriul românesc circulă, la momentul publicării traducerii în română, varianta în ebraică și idiş, în comunitățile evreiești ${ }^{7}$, și cea în maghiară ${ }^{8}$, publicată la Cluj-Napoca în 1783. Traducătorul maghiar este lingvistul clujean Sámuel Gyarmathi (1751-1830), autor al unei foarte apreciate lucrări de istorie comparată a limbilor fino-ugrice - Affinitas lingue hungarice cum linguis fennice originis grammatice demonstrata (Göttingen, 1799), prima demonstrație științifică a apartenenței limbii maghiare la familia finougrică, și al primului dicționar etimologic unguresc, Vocabularium (Viena, 1816), care compară vocabularul maghiar cu alte 57 de limbi, printre care și româna.

Traducerea în română este realizată de Nicola Nicolau (1762-1837), care provenea dintr-o veche şi înstărită familie de negustori din Brașov (Iorga, 1931, p. 75), gustul pentru operele literare fiind alimentat de călătoriile sale prin Europa, în scop comercial. Din cauza dificultăţilor financiare, acceptă un post de dascăl la școala din Șcheii Brașovului (1828-1829), iar în 1830 este numit director al școlii întemeiate de Dinicu Golescu în Țara Românească (Mureșianu, 1931). Alături de Ioan Piuariu-Molnar și Gavril Onișor, este membru al „Soțietății filosoficești a neamului românesc în Mare Prințipatul Ardealului”, societate de tip enciclopedic şi voltairean, fondată la 1795, în scopul cultivării limbii și culturii române, și care era în legătură cu cărturari din Muntenia, precum Enache Văcărescu (Pop, 1946, p. 6). Programul societății prevedea publicarea unei reviste, pentru care însă nu este primită aprobare de la Viena, și care ar fi cuprins teme din domenii diverse (teologie, geografie, istorie, fizică, matematică, filozofie, farmacie, nutriție), reprezintînd astfel prima inițiativă de popularizare a științelor (Pop, 1946, p. 6). Printre cărțile enunțate în programul societății se număra și o lucrare de geografie, care, conform Iorga, ar fi tocmai cea publicată de Nicolau (Bordaș, 2006, p. 78) în 1814 la Tipografia Universităţii din Buda, sub titlul Gheografia sau Scrierea Pământului, întocmită după orînduiala cea mai noao, așezată pentru 4 părți ale Pămîntului, adecă: Europa, Asia, Africa, America cu tot cuprinsul lor. Acest text reprezintă în fapt o prelucrare a Geografiei lui Amfilohie Hotiniul, din 1795, tradusă după Claude Buffier, căreia Nicolau îi adaugă şi alte date, culese

\footnotetext{
${ }^{6}$ Cuvîntul maskil desemnează un învățat evreu autodidact, care trăia într-o țară slavonă și era cunoscător al unei limbii vii (de regulă, germana).

7 "Columbus was written so beautifully that it could be read and understood everywhere - in Russia, Poland, Galicia and Romania, every place where Jews were to be found." (A. B. Gottlober, Memories and Travels (2), Ierusalim, 1976, p. 15-17, apud Shavit, 1995, p. 78).

${ }^{8}$ Amérikának fel-találásáról: a gyermekek és az ifjak kedvekért.
} 
cu prilejul numeroaselor sale călătorii în interes de negoț. Încă din această lucrare este evident interesul lui Nicolau pentru Lumea Nouă, căci include în volumul II două capitole pe această temă: primul despre Cotez - O întîmplare și istorie eroicească din vremea cînd spaniolii intrară spre stăpînirea unora locuri din America prin ghenerariul Corteț (p. 72-119), al doilea despre Columb - Cristof Columbus, care au aflat America întîiu, s-au născut la anul 1441 și muri la anul 1506 (p. 120-124), pentru care nu se cunoaște textul sursă. Camară $(2017$, p. 27) observă că nu există nici un raport de filiație între textul despre Columb din Gheografia și Descoperirea Americii, chiar dacă sînt prezentate aceleași evenimente. Pe lîngă cele menționate mai sus, Nicolau mai scrie și Calendariul pe 1814, Plutarh nou (1819) - traducere conținînd portrete de oameni celebri, căreia îi adaugă unele figuri autohtone, Învăţături și îndemnuri (1830), manuscrisul Mult de lipsă și folositoare învățături și științe despre mai multe lucruri (1832), conținând un text tradus din neogreacă (Ursu \& Ursu, 2004, p. 398), și manuscrisul Testament, redactat în anii 1793, 1796 și 1819 în românește și greacă și care conține un set de învățături morale.

Deși în text nu este numit traducătorul, fiind menționat doar că a fost tipărit „cu toată cheltuiala lui Nicola Nicolau din Brașov”, iar postfaţa este semnată de „un iubitoriu de neamul românesc”, Iorga (1931, p. 2) afirmă că negustorul braşovean ar fi traducătorul Descoperirii Americii, căci lucrarea se caracterizează prin „aleasa formă literară (...), caligrafia perfectă”. Volumul apare la 1816 la Tipografia Universității din Buda, unde, la sfîrșitul secolului al XVIII-lea şi începutul celui de-al XIX-lea, au activat învăţaţi care, prin publicarea de carte în limba română (cărți de autor și traduceri), au militat pentru păstrarea identității românești (a limbii și culturii române) în teritorii dominate de alte naţionalități, limbi și culturi - maghiară, austriacă, ce făceau parte din Imperiul Habsburgic. În perioada 1780-1830, la Tipografia Universității din Buda au fost tipărite aproximativ 240 de cărți în limba română, mare parte dintre acestea fiind laice (Tatay, 2011, p. 1).

În postfață, Nicolau justifică publicarea cărții prin faptul că românii nu cunoșteau date despre descoperirea Americii: „nici toți oamenii de acest națion au știre, cum, cînd, și în ce chip sau aflat acest mai înainte necunoscut pămînt și parte noao a lumei" ", căci scrierile istorice în limba română erau rare în acele timpuri: „Asemenea istorii neobicinuit fiind a se tipări pre limba romănească”. Știința trebuie să se alinieze cu iluminarea europeană: „precum și celelalte națione foarte se îngrijesc pentru deșteptarea tinerilor întru aceste adevărate iară nu iscodite istorii”, fiind afirmat astfel caracterul istoric al textului. În final, rezumă volumele II și III din seria Die Endekkung von Amerika: „După moartea lui, multe locuri și țări necunoscute, dară foarte mari și bogate de aur și alte scumpeturi firești, prin alți bărbați asemenea acestuia vredinici, se aflară. Multe feliuri de războae urmară cu oamenii după acele locuri, pănă se putură stăpăni de alte crăii din Europa” (p. 191-198).

Din Descoperirea Americii de Joachim Heinrich Campe, Nicola Nicolau traduce şi adaptează doar primele 18 povestiri din cele 20 din volumul despre Columb, și anume nu traduce povestirile 19 și 20, intitulate Anexă pentru cei care doresc să citească şi a doua parte a acestei opere, și în care se arată ce s-a întîmplat în continuare cu coloniile spaniole întemeiate de Columb şi care a fost soarta echipajului, a colonizatorilor și a familiei acestuia. Dacă întreaga serie a operelor lui Campe despre America se numește Die Entdekkung von Amerika. Ein angenehmes und nüzliches Lesebuch für Kinder und junge Leute [Descoperirea Americii. O carte plăcută și folositoare pentru copii și tineret], iar primul volum este intitulat Kolumbus oder die Entdekkung von Westindien [Columb sau descoperirea Vest-Indiei], Nicolau reține doar: Descoperire Americii. O carte foarte folositoare. Renunță probabil la numele lui Columb din titlu, întrucît, aşa cum scrie în postfaţă, intenţionează să traducă întreaga serie, dacă tema va stîrni interesul publicului. Spre deosebire de originalul german, omite a menționa publicul țintă, căci vizați sînt nu doar copiii și tineretul, în ciuda faptului că menține rama povestirii, forma dialogată care, conform lui Campe, ar facilita înțelegerea de către publicul tînăr. În sfîrșit, renunță la adjectivul angenebmes Lesebuch [carte plăcută], punînd accentul doar pe utilitatea lecturii. De asemenea, nu este tradusă nici prefaţa autorului. În locul copiiilor din originalul german (Nikolas, Gottlieb, Kristel, Konrad, John, Hans, Johannes, Die-

\footnotetext{
${ }^{9}$ Transliterarea fragmentelor din Descoperirea Americii (1816) este realizată de autoarea acestui articol.
} 
derich, Peter, Ferdinand, Mathias, Karl, Fritz, Lotte), între care se numără și fetele Lotte și Kristel, tatăl se adresează băieților cu nume românești, Ioan, Andrei și Luca. Spre deosebire de varianta germană, mama nu este chemată să asculte povestirea, aceasta intră însă în scenă episodic.

\section{Strategii de traducere}

Omisiunile, interpolările și calcurile sînt strategii frecvent utilizate de Nicolau în redactarea textului românesc. Analiza traductologică comparativă a scos la iveală că, pe lîngă omiterea traducerii ultimelor două povestiri, Nicolau recurge și la alte omisiuni, care variază ca lungime: de la fragmente care se întind pe una sau două pagini până la cuvinte sau părți dintr-o frază. Vom oferi mai jos doar cîteva exemple. Traducătorul renunță la cîteva dialoguri din textul sursă, spre exemplu cînd în ramă se discută termenii germani kreuzen și entern (p. 2-3), întrucît simplifică textul, optînd să nu redea sensul acestor cuvinte specializate (desemnînd termeni de navigație), ci doar să relateze întîmplările (p. 5-6). Din a patra povestire nu traduce prima parte, și anume o lecție de geografie, în care sînt explicate coordonatele globului. Omisiuni mai scurte se pot observa în exemplele de mai jos. Ca referință pentru varianta germană s-a folosit ediția din anul 1782, publicată la Tübingen.

\begin{tabular}{|c|c|c|}
\hline Text sursă & Traducere & Observații \\
\hline $\begin{array}{l}\text { In kurzer Zeit hatt' er so viel davon gefaßt, daß er nun } \\
\text { zu den Wissenschaften selbst geführet werden konte. } \\
\text { Und da hättet ihr sehen sollen, wie gierig er jedes Wort } \\
\text { verschlang, das aus dem Munde seiner Lehrer fiel! In } \\
\text { kurzer Zeit hat er in der Erdbeschreibung, Meßkunst, } \\
\text { Astronomie und im Zeichen so erstaunliche Schritte } \\
\text { gethan ... (p. 7) }\end{array}$ & $\begin{array}{l}\text { Și în scurtă vreme așa mult învăță, cît } \\
\text { putea să pășească spre învățăturile } \\
\text { cele mai mari. În scurtă vreme în } \\
\text { științele geografiei, astronomiei, și a } \\
\text { însămnării, adecă a însămna pre scris } \\
\text { ori ce lucru va vedea, atîta să } \\
\text { deșteptase... (p. 4) }\end{array}$ & \\
\hline $\begin{array}{l}\text { Nach einer Reise in den nördlichen Ozean, auf der } \\
\text { seine Einsichten ungemein erweitert wurden, trat er in } \\
\text { die Dienste eines seiner Anverwandten, eines } \\
\text { Seekapitains, der auf seine eigene Kosten einige Schiffe } \\
\text { ausgerüstet hatte... (p. 9) }\end{array}$ & $\begin{array}{l}\text { Un căpitan de corăbii, cu care el se } \\
\text { rudi, avea ale sale însuși corăbii, supt } \\
\text { acărui slujbă intră și el... (p. 5) }\end{array}$ & \\
\hline $\begin{array}{l}\text { Dieses Aus- und Einladen, und dieses Fortbringen zu } \\
\text { Lande vom rothen Meere bis nach Alexandrien, } \\
\text { erschwerten nun den Handel nach Ostindien gar sehr } \\
\text { (p. 15) }\end{array}$ & $\begin{array}{l}\text { Această încărcătură și descărcătură, și } \\
\text { asemenea greutăți, foarte tare } \\
\text { îngreuea neguțătoria la Ost-India. } \\
\text { (p. 9) }\end{array}$ & \\
\hline $\begin{array}{l}\text { Mutter. Nahm er denn seine Frau nicht mit auf diesen } \\
\text { Reisen? } \\
\text { Vater. Ich glaube, nein! Weil keiner seiner Geschichts- } \\
\text { schreiber dieses Umstandes erwähnt hat. } \\
\text { Lotte. O Mutter, nun machst du es wieder eben so, wie } \\
\text { bei der Robinsonsgeschichte! Wenn man meint, daß es } \\
\text { eben recht angehen sol: so rufst du uns immer ab. } \\
\text { Gottlieb. O laß nur, Lotte! Das thut ja Mutter nur, um } \\
\text { uns in der Enthaltsamkeit zu üben: weist du nicht? } \\
\text { Lotte. Ja, aber - } \\
\text { Alle. Zur Arbeit! Zur Arbeit! Zur Arbeit! (p. 16) }\end{array}$ & $\begin{array}{l}\text { Acestea povestind lor, intră mama lor } \\
\text { în casă, și le zise: acum ca ajungăvă a } \\
\text { povesti, veniți și la alt lucru. Și Tatăl } \\
\text { încă încetă de astă dată a mai spune } \\
\text { lor. (p. 10) }\end{array}$ & $\begin{array}{l}\text { Nu traduce întrebarea } \\
\text { soției, curioasă dacă } \\
\text { Columb era însoțit de } \\
\text { soția sa. De asemenea, } \\
\text { este omisă și referința la } \\
\text { Robinson. }\end{array}$ \\
\hline
\end{tabular}

Omisiunile necesită de multe ori reformularea și simplificarea din partea traducătorului român:

\section{Text sursă}

Er war beherzt und munter; liebte nicht die träge Ruhe und weibliche Gemächlichkeit; verschmähte frühzeitig alle Lekkereien, die zwar den Gaum kizeln, aber auch die Gesundheit schwächen: er war ein Feind von Müßiggehn und von allen läppischen Doffen, die auf gar nichts Nützliches abzielen. (p. 7)

\section{Traducere}

nu iubea lenevirea și odihna, nici mîncări, care îndulcea numai gîtul său, și sănătatea strica, fiind dușman lucrărişor zadarnice și fără de folos. (p. 4)
Observaţii

Scurtează textul, renunțînd la o serie de adjective, folosite în original în cadrul unor expresii. 
Indem er bald die Kanarischen Inseln, bald die Küste von Afrika, und bald die Azoren besuchte. (p. 15) cînd ostrovile Canaricești, cînd țărmurile Africei, și alte, cerceta. (p. 10)
Optează a omite menționarea insulelor Azore, din original, înlocuiește cu alte.

Mai rar întîlnim adăugiri/interpolări, atunci cînd traducătorul dorește să ușureze lectura:

\section{Text sursă}

Vor ungefähr 300 Jahren lebte zu Genua in Italien ein Mann (p. 6)

\section{Traducere}

Sînt peste 300 de ani, de cînd în Italia, la cetatea Genova trăia un om (p. 3)

\begin{abstract}
Von seiner Herkunft weiß man nicht viel mehr, als, daß seine Voreltern sich von der Schiffarth nährten. Das war denn auch wohl die Ursache, warum auch er, von früher Jugend an, eine große Neigung zu dem Seewesen äußerte, und sich endlich diesem Stande wirklich widmete. (p. 6)
\end{abstract} cît strămoșii lui se hrănea cu călătorii spre mare, și tatăl acestui Columbus era locrătoriu de mătasă, după cum spun alți istorici. Dară el mai mult se aplecă spre meșteșugul strămoșesc,
De neamul său mai mult nu se știe, de adecă a călători spre mare, de cît a fi meșter. Aceasta trebue să fi fost și pricina, de a se da și însuși cu totul spre călătoria mării. (p. 3-4)

\begin{tabular}{|c|c|c|}
\hline gute Hofnung (p. 11) & Bona Speranza, Bunei Nădejde (p. 9) & $\begin{array}{l}\text { Adaugă și denumirea în } \\
\text { spaniolă. }\end{array}$ \\
\hline $\begin{array}{l}\text { Er ermunterte ihn, ein so großes Projekt doch, je eher, } \\
\text { je lieber, zur Ausführung zu bringen. (p. 20) }\end{array}$ & $\begin{array}{l}\text { îndămnînd pre dînsul cît mai îngrab, } \\
\text { atît mai bine, în săvărșire să aducă, } \\
\text { acele necunoscute țări ale căuta. } \\
\text { (p. 13) }\end{array}$ & \\
\hline
\end{tabular}

Observații

Presupunere că cititorul român are mai puține cunoștințe despre Genova. Întrucît introduce informații suplimentare, trebuie să reformuleze.

Nicolau se dovedește a fi un traducător iscusit, care știe să adapteze textul scurtat, însă se strecoară pe alocuri și câteva greșeli/devieri:

\section{Text sursă}

Er verheiratete sich nemlich, und zwar mit der Tochter eines Seekapitains, welcher einer der ersten Entdekker der Inseln Porto Santo und Madeira gewesen war. (p. 15)

Dennoch vergaß er nicht, daß Irren menschlich sei (p. 19)

\section{Traducere}

El se căsători, și luă pre fata unui căpitan de mare, care era acel din tîiu aflătoriu Ostrovilor Porto-Santo, și Madeira. (p. 10)

Cu toate acestea, uită el, că a greși e slăbiciune omenească (p. 12)
Observații Corect: „unul dintre cei dintîi...”.

Omite traducerea lui nu, care schimbă sensul propoziției.

Se pot observa și alte fenomene, specifice traducerilor din acea perioadă: echivalențe/calcuri: Ruder (p.9) - rudă (p. 4); Hauptstadt (p. 10) - căpetenia cetate (p. 7); Ostindien (p. 11) - Ost-India (p. 7); Südpol (p. 13) - Sidpol (p. 8); Aus-und Einladen (p. 15) - incărcătură și descărcătură (p. 9); bekam in die Hände (p. 15) - intrară în mînile lui (p. 10); și glose sub formă de note de subsol: Drei Viertel einer deutschen Meile (p. 9) - Trei fârtale de un mil nemțesc ( ${ }^{*}$ Un grad, care 15 miluri geograficești sau nemțești ține, se socotește 20 miluri de mare.) (p. 4); der Rath von Genua (p. 20) - Magistratul Genovii ( ${ }^{*}$ divanul) (p. 14).

\section{Concluzii}

Strategiile exemplificate pe scurt sînt utilizate de Nicolau în scopurile enunțate în postfață, ale producerii textului în limba română:

- transmiterea mai facilă a informațiilor istorice și geografice, prin omiterea acelor date care i se par inutile și ar îngreuna lectura, sau, dimpotrivă, prin interpolări care oferă date suplimentare unui cititor mai puțin obișnuit cu texte istorico-geografice, precum era cititorul român al acelor timpuri; 
- traducerea fidelă a învățăturilor morale - element specific lucrărilor didactice iluministe, transmise sub formă de dialog între tată și copii, prin care sînt comentate conduita și reacțiile, acțiunile personajelor, care constituie modele sau anti-modele pentru tînărul cititor;

- îmbogățirea limbii române, prin introducerea de calcuri și glose și astfel a unui limbaj de specialitate.

Scopul unuia din primele romane pentru tineret, Die Endekkung von Amerika, este răspîndirea ideilor iluministe: de educație morală, inclusiv propagare a toleranței (faţă de amerindieni), și culturalizare a maselor, prin transmiterea de cunoștințe istorico-geografice. Acest obiectiv este atins și prin versiunile în alte limbi europene: datele istorice interpretate în spirit iluminist de istoricul scoțian William Robertson, prelucrate tot în spirit iluminist pedagogic de scriitorul german Joachim Heinrich Campe, sînt introduse în culturile receptoare, adăugîndu-se ideea de cultivare a limbii și identității naţionale. În textul românesc, forma dialogată, element specific lucrărilor didactice iluministe, este menținută, însă adaptată la contextul receptor, prin redenumirea personajelor cu nume românești. Scopul de cultivare a limbii române reiese atît din pagina de gardă, unde traducătorul în limba română, Nicola Nicolau, se prezintă ,un iubitoriu de neamul românesc”, care publică „cu toată cheltuiala” această carte în limba română, din postfață, precum și din traducerea infidelă și strategiile traductive.

\section{Bibliografie}

Agori, M. (2005). A Marginal(ized) Perspective on Translation History: Women and Translation in the Eighteenth Century, în „Meta. Journal des traducteurs", 50 (3), p. 817-830, Crossref.

Blamires, D. (2009). Telling Tales. The Impact of Germany on English Children's Books 1780-1918, Open Book Publishers, Cambridge.

Bordaș, L. (2006). Imaginea Indiei în primele cărți de istorie și geografie tipărite în românește, în Bogdan, A. (ed.), In honorem Gabriel Strempel, Ed. Muzeului Sătmărean, Satu-Mare, p. 78-97.

Camară, I. (2017). Izvoare: traducerile și cursele lor, în Gînsac, 2017, p. 15-60.

Campe, J.H. (1782). Kolumbus oder die Entdekkung von Westindien. Ein angenehmes und nützliches Lesebuch für Kinder und junge Leute, Frank und Schramm, Tübingen.

Campe, J.H. (1816). Descoperirea Americii, traducere în română de Nicolau, N., Tipografia Universității din Buda, Buda.

Chindriș, I. et al. (2016). Cartea românescă veche în Imperiul Habsburgic (1691-1830). Recuperarea unei identități culturale, Mega, Cluj-Napoca.

Delisle, J. \& Woodsworth, J. (eds) (1995). Translators through History, John Benjamins, Amsterdam, Crossref.

Dietz, F. (2019). Mediated education in early modern travel stories: How travel stories contribute to children's empirical learning, în „Science in Context”, 32 (2), p. 193-212, Crossref.

Even-Zohar, I. (1990). Laws of Literary Interference, în „Polysystem Studies. Poetics Today”, 11 (1), p. 53-72, Crossref.

Gheție, I. (1982). Introducere în studiul limbii române literare, Editura Științifică și Enciclopedică, București.

Gînsac, A.M. (coord.) (2017). Practici de traducere a numelor proprii în scrisul românesc premodern (1780-1830), Editura Universității „Alexandru Ioan Cuza”, Iași.

Iorga, N. (1931). Testamentul lui Nicola Nicolau, în „Memoriile Secțiunii Istorice”, seria III, tomul XII, mem. 7, Academia Română, p. 75-87.

Mureșianu, A. (1931). Contribuție la istoria vechei familieii brașovene a Nicolaeștilor, în „Țara Bârsei”, III (4), p. 314-334.

Neculau, N. (1814). Gheografia sau Scrierea Pământului, întocmită după orînduiala cea mai noao, așezată pentru 4 părți ale Pămîntului, adecă: Europa, Asia, Africa, America cu tot cuprinsul lor, Tipografia Universității din Buda.

Petroff, F. (2017). William Robertson's Unfinished History of America. The Foundation of the British Empire in North America and the Scottish Enlightenment, în „Transatlantica. American Studies Journal”, 2, p. 1-17, Crossref.

Polioudakis, G. (2008). Die Übersetzung deutscher Literatur ins Neugriechische vor der Griechischen Revolution von 1821, Peter Lang, Frankfurt am Main.

Pop, E. (1946). „Societatea filosofească...” din 1795, în „Transilvania”, 77 (1-4), p. 1-15.

Shavit, Z. (1993). Literarische Beziehungen zwischen den deutschen und der jüdisch-hebräischen Kinderliteratur in der Epoche der Aufklärung am Beispiel von J. H. Campe, în Frank, A. P. et al. (eds), Übersetzen, verstehen, Brücken bauen. Geisteswissenschaftliches und literarisches Übersetzen im internationalen Kulturaustausch, vol. II, Erich Schmidt Verlag, Berlin, p. 755765, [online].

Shavit, Z. (1995). Intercultural Relationships. The Importance of the Study of Cultural Interference for the Historical Study of Children's Literature. Test Case: The Relations Between German and Jewish Children's Literatures During the 18th and 19th Centuries, în „Compar(a)ison”, 2, p. 67-80, [online].

Tatay, A.E. (2011). Gravurile in metal din cartea lui I. H. Kampe, Descoperirea Americii, Buda, 1816, în „Libraria. Studii și cercetări de bibliologie”, X, p. 176-187. 
Ursu, N.A. \& Ursu, D. (2004). Imprumutul lexical în procesul modernizării limbii române literare (1760-1860), vol. I, Cronica, Iași.

Vermeer, H.J. (1978). Ein Rahmen für eine allgemeine Translationstheorie, în „Lebende Sprachen”, 23 (3), p. 99-102, Crossref.

Völpel, A. \& Shavit, Z. (2002). Deutsch-jüdische Kinder-und Jugendliteratur. Ein literaturgeschichtlicher Grundriß, J. B. Metzler, Stuttgart/Weimar.

Werner, M. \& Zimmermann, B. (2006). Beyond Comparison: Histoire Croisée and the Challenge of Reflexivity, în „History and Theory", 45 (1), p. 30-50, Crossref. 